\title{
The Psychological and Socio-Political Consequences of Infectious Diseases: Authoritarianism, Governance, and Nonzoonotic (Human-to-Human) Infection Transmission
}

\author{
Leor Zmigrod ${ }^{1,2}$, Tobias Ebert ${ }^{3}$, Friedrich M. Götz ${ }^{1,4}$, Peter Jason Rentfrow ${ }^{1}$ \\ [1] Department of Psychology, University of Cambridge, Cambridge, United Kingdom. [2] Behavioural and Clinical Neuroscience Institute, University of \\ Cambridge, Cambridge, United Kingdom. [3] Mannheim Centre for European Social Research, University of Mannheim, Mannheim, Germany. [4] Institute of \\ Personality and Social Research, University of California, Berkeley, CA, USA.
}

Journal of Social and Political Psychology, 2021, Vol. 9(2), 456-474, https://doi.org/10.5964/jspp.7297

Received: 2020-09-25 • Accepted: 2021-06-01 • Published (VoR): 2021-09-09

Handling Editor: Fouad Bou Zeineddine, University of Innsbruck, Innsbruck, Austria

Corresponding Author: Leor Zmigrod, Department of Psychology, University of Cambridge, CB2 3EB, United Kingdom. E-mail: Lz343@cam.ac.uk

Supplementary Materials: Data, Materials [see Index of Supplementary Materials]

\begin{abstract}
What are the socio-political consequences of infectious diseases? Humans have evolved to avoid disease and infection, resulting in a set of psychological mechanisms that promote disease-avoidance, referred to as the behavioral immune system (BIS). One manifestation of the BIS is the cautious avoidance of unfamiliar, foreign, or potentially contaminating stimuli. Specifically, when disease infection risk is salient or prevalent, authoritarian attitudes can emerge that seek to avoid and reject foreign outgroups while favoring homogenous, familiar ingroups. In the largest study conducted on the topic to date ( $\mathrm{N}>240,000)$, elevated regional levels of infectious pathogens were related to more authoritarian attitudes on three geographical levels: across U.S. metropolitan regions, U.S. states, and cross-culturally across 47 countries. The link between pathogen prevalence and authoritarian psychological dispositions predicted conservative voting behavior in the 2016 U.S. Presidential Election and more authoritarian governance and state laws, in which one group of people imposes asymmetrical laws on others in a hierarchical structure. Furthermore, cross-cultural analysis illustrated that the relationship between infectious diseases and authoritarianism was pronounced for infectious diseases that can be acquired from other humans (nonzoonotic), and does not generalize to other infectious diseases that can only be acquired from nonhuman species (zoonotic diseases). At a time of heightened awareness of infectious diseases, the current findings are important reminders that public health and ecology can have ramifications for socio-political attitudes by shaping how citizens vote and are governed.
\end{abstract}

\section{Keywords}

authoritarianism, infectious diseases, behavioural immune system, ideology, political attitudes, political governance, cross-cultural, geographical psychology

\section{Non-Technical Summary}

\section{Background}

Does the prevalence of infectious diseases shape a region's socio-political outcomes? The Parasite Stress Theory of Sociality hypothesizes that when infections are high, human beings will avoid dissimilar others and will show preferences for obedience and conformity. In the largest study to date, the present study examined over 240,000 participants in 47 countries to investigate 
whether a region's prevalence of pathogens is related to its citizens' levels of authoritarianism. The investigation also explored whether the infections-authoritarianism link could explain large political outcomes such as conservative voting behavior and more authoritarian legal governance.

\section{Why was this study done?}

It is imperative to understand how public health relates to political behavior. Can a need to avoid infections shape human beings' political cognition and preferences of obedience and conformity? If so, it is essential to clarify the strength of this relationship, whether it recurs in multiple geographical locations and levels, as well as whether it is specific to certain kinds of diseases but not others.

\section{What did the researchers do and find?}

The analysis revealed a robust relationship between individuals' authoritarian attitudes and their region's levels of infectious diseases: areas with greater prevalence of infectious diseases had more authoritarian citizens. Moreover, these areas with high infection rates tended to vote conservatively and were also governed by more authoritarian laws (laws that are imposed hierarchically on some members of society but not all). This pattern was evident when comparing 47 nations, as well as between US states and fine-grained metropolitan regions and cities. These effects persisted after accounting for regional demographic variables such as educational attainment, wealth, and inequalities, suggesting direct and significant relationships between infectious diseases and authoritarian beliefs and behaviors.

\section{What do these findings mean?}

These results indicate that the prevalence of infectious diseases is positively linked to people's authoritarian attitudes and the degree to which their nation or region is governed in an authoritarian manner. Notably, the findings show that these patterns are consistent when studied between nations, between US States, and between US Metropolitan Regions. Perhaps most importantly, authoritarian attitudes were only related to infectious diseases that can be transmitted between humans (nonzoonotic diseases) - and not ones that are purely transmitted between non-human animals - illustrating that there is a fundamentally social mechanism at work here. Diseases that enforce social avoidance can breed authoritarian attitudes and outcomes, but not asocial diseases. Consequently, infectious diseases that can be transmitted human-to-human (such as COVID-19) have the potential to shape a region's authoritarianism. Policymakers can therefore benefit from understanding how public health outbreaks can impact citizens' political proclivities.

The behavioral immune system (BIS) is a highly adaptive motivational system that diminishes infection risk by altering information processing and behavior to prevent pathogen transmission (Ackerman, Hill, \& Murray, 2018). The system detects potentially-threatening environmental stimuli and promotes cognitive and affective reactions that reduce contact with these stimuli. For instance, upon sight of a potentially contaminating substance, humans typically experience the emotion of disgust, which fosters aversion and avoidance. Similarly, ecological conditions characterized by high levels of infectious diseases can promote behavioral adaptations associated with conforming to established traditions and avoiding foreign and potentially-infectious stimuli (Faulkner, Schaller, Park, \& Duncan, 2004; Fincher \& Thornhill, 2012; Navarrete \& Fessler, 2006). By encouraging the individual to minimize contact with unfamiliar targets and to seek targets that are known and recognizable, the BIS provides a "first line of defense against contamination" (Terrizzi, Shook, \& McDaniel, 2013).

Research in social psychology has illustrated that disease-avoiding motivations can have profound implications for social behavior and cultural outcomes: activating the BIS with threat-relevant cues leads individuals to avoid unfamiliar social targets and to conform to familiar social targets. Specifically, two lines of empirical evidence have converged in support of the hypothesis that human motivations to avoid pathogens shape socio-political attitudes by facilitating hostility towards outgroups and augmenting preferences for social conformity. Firstly, at the level of individual psychology, when the perception of infection risk is elevated, individuals tend to adopt more conformist and conservative attitudes (Helzer \& Pizarro, 2011; Inbar, Pizarro, \& Bloom, 2009; Jones \& Fitness, 2008; Murray \& Schaller, 2012, 2016; Wu \& Chang, 2012). Furthermore, individuals who experience greater levels of disgust in response 
to pathogen cues are more likely to endorse more xenophobic, ethnocentric, morally-vigilant attitudes (e.g., Navarrete \& Fessler, 2005; Faulkner et al., 2004; Liuzza et al., 2018, 2019; Murray, Kerry, \& Gervais, 2019; Schnall, 2017; Stewart, Adams, \& Senior, 2020; Zakrzewska et al., 2019; but see: van Leeuwen \& Petersen, 2018). Consequently, an individual's sensitivity to contamination-related and disgust-provoking cues may fundamentally shape their socio-political attitudes.

The second line of evidence comes from cross-population studies, which have found associations between geographical variations in pathogen prevalence and the emergence of more ethnocentric, collectivist, and conservative cultural attitudes. Higher levels of parasite stress are related to greater regional political authoritarianism and social conservatism (Murray, Schaller, \& Suedfeld, 2013; Terrizzi, Shook, \& McDaniel, 2013; Thornhill, Fincher, \& Aran, 2009; but see: Horita \& Takezawa, 2018), prioritization of obedience and intolerance of nonconformity (Murray, Trudeau, \& Schaller, 2011; Tybur et al., 2016), heightened collectivism and endorsement of binding moral concerns (Fincher, Thornhill, Murray, \& Schaller, 2008; van Leeuwen, Park, Koenig, \& Graham, 2012), moral vitalism (Bastian et al., 2019), and increased frequency of intrastate armed conflict (Letendre, Fincher, \& Thornhill, 2010). Therefore, the higher ecological prevalence of infectious diseases appears to promote societal norms that are more conservative and authoritarian.

Therefore, the current study combined the methodologies of individual-focused psychology and cross-population studies to test whether regional pathogen prevalence promotes authoritarian psychological dispositions, which in turn shape real-world political outcomes. Specifically, it sought to address three primary questions: (Q1) Are higher rates of infectious diseases related to more authoritarian attitudes? (Q2) Does the relationship between infectious diseases and authoritarian attitudes explain real-world outcomes such as voting behavior and law? And (Q3) is this effect specific to infections that can be acquired from humans (nonzoonotic diseases, i.e., "socially-relevant infections") as opposed to infections that can be acquired only from non-human species (zoonotic diseases, "asocial infections")? Addressing these questions would elucidate the psychological mechanisms underlying the effect of infectious diseases on socio-political outcomes.

\section{Method and Materials}

The data consisted of 258,241 participants and included 206,308 participants residing in the USA. The rest $(N=$ $51,933)$ were residents of 46 other nations. The data were collected between June 2017 and October 2018 as part of a collaborative project between the authors and TIME Magazine (see Ebert, Götz, Obschonka, Zmigrod, \& Rentfrow, 2019; Götz, Bleidorn, \& Rentfrow, 2020), with the approval of the Psychology Research Ethics Committee of the institution (including a waiver of parental consent; application number: PRE.2017.044). The study was carried out as an online survey hosted, launched, and advertised by TIME Magazine (https://time.com/4809884/harry-potter-house-sorting-hat-quiz/) and included two parts, only available in English. The first part allowed people to complete established personality tests and receive feedback about their personality profile and how this would theoretically relate to the four fictional Hogwarts Houses from the Harry Potter saga. The second part of the project- on which the present dataset is based included an additional survey that was independent of the first Harry Potter-themed survey. Participants were invited to complete this survey for additional scientific purposes. The survey included the authoritarianism measure used here. Participants consented and opted-in to completing the second survey for research. They received no feedback on this second survey, so there was no incentive other than research participation. For each participant, we examined their authoritarianism score, age, gender, and zip code.

We used a participant's zip code to aggregate the 258,241 individual authoritarian scores to the level of U.S. Combined Statistical Areas, U.S. States, and nations. Following previous geo-psychological studies (e.g., Gebauer et al., 2017), we only kept spatial units with at least 100 observations. As is typical for online studies (Gosling, Vazire, Srivastava, \& John, 2004), our sample overrepresented female $(75.5 \%)$ and young $\left(M_{\text {Age }}=31.02, S D=10.29\right)$ participants. Therefore, we followed previous research (Ebert et al., 2019; Stuetzer et al., 2018) and applied post-stratification to account for this skewed sample composition. Specifically, we created six categories consisting of three age groups (18-24, 25-34, and older than 34) for both genders. We then calculated sampling weights by dividing the share per age-gender category in our sample by the share of people per age-gender category in the actual population. That way, 
a person underrepresented in our data (e.g., an old male) receives a greater weight than one, while a person who is overrepresented (e.g., a young female) receives a weight smaller than one.

\section{Individual-Level Measures}

\section{Authoritarianism}

Participants were invited to complete an authoritarianism personality survey, in which they were presented with four pairs of traits and were asked to indicate the quality that they believed is more important for a child to possess: "independent or respectful"; "obedient or self-reliant," "well-behaved or considerate," and "well-mannered or curious." This measure has been widely used in social and political psychology (e.g., Brandt \& Reyna, 2014; Brandt \& Henry, 2012; Crawford, Brandt, Inbar, \& Mallinas, 2016; Federico, Fisher, \& Deason, 2011; Feldman \& Stenner, 1997; Hetherington \& Suhay, 2011; Hetherington \& Weiler, 2009; Stenner, 2005; Zmigrod, Rentfrow, \& Robbins, 2018; Zmigrod et al., 2021) and does not conflate authoritarianism with political ideology or fundamentalism, unlike other authoritarianism measures (Hetherington \& Weiler, 2009; Mavor et al., 2009, 2011; Stenner, 2005). To quantify the authoritarianism measure's reliability, we computed the ordinal polychoric correlation-based reliability coefficients (Gadermann, Guhn, \& Zumbo, 2012), as these suit the ordinal item structure of the authoritarianism measure. This illustrated good reliability for the authoritarianism measure across the 258,241 participants for all available ordinal reliability indices: ordinal $\alpha=.70$, ordinal omega total $=.78$, Guttman's $\lambda 2$ and $\lambda 6=.70$ and .65 , Guttman's $\lambda 4$ maximum split-half reliability $=.78$, and estimated greatest lower bound (GLB) based upon communalities $=.79$. As noted above, the aggregated authoritarianism measure presented in the analyses was standardized and weighted by age and gender to account for any skewed sample composition.

\section{Regional-Level Measures}

\section{Pathogen Prevalence Measures}

To quantify regional pathogen prevalence across the three levels of geographical analysis, we followed literature standards in calculating regional infectious diseases or historical pathogen prevalence rates, using multiple pathogen prevalence indices to replicate effects wherever data were available. To calculate regional infectious diseases or historical pathogen prevalence rates, we followed established measures developed by past research.

Infectious disease prevalence: U.S. metropolitan regions - Following Hackman and Hruschka's (2013) methodological recommendations, we obtained the number of cases of chlamydia and gonorrhea for each U.S. county from the Centers for Disease Control (CDC). We aggregated this data to the level of metropolitan regions (Combined Statistical Areas), and calculated chlamydia and gonorrhea cases per 100,000 people for each year between 2002 and 2010. To account for annual fluctuations, our final index consisted of the average rate across these 9 years.

Infectious disease prevalence: U.S. states - The CDC provides more extensive information on infectious diseases at the state level than the county level, so for the state level, we relied on an index compiled by Fincher and Thornhill (2012), which quantified the pathogen prevalence of all infectious diseases tracked by the CDC. Each state has a numerical value equal to the average $z$-score of a population-adjusted disease incidence score for 1993 to 2007. Fincher and Thornhill (2012) noted that the standardization of the state variables produces a metric that evaluates a state's relative position in terms of parasite stress. We also aggregated the CDC index used above to calculate pathogen prevalence for the U.S. metropolitan regions to create a state-level measure. All analyses replicated the Fincher and Thornhill measure.

Infectious disease prevalence: Nations - Two measures were used to calculate pathogen prevalence at the national level. (1) Historical prevalence of disease-causing parasites (Murray \& Schaller, 2010). This index is a numerical estimate of the relative overall historical prevalence of disease in the country, based on nine different infectious diseases (leishmanias, trypanosomes, leprosy, schistosomes, filariae, tuberculosis, malaria, dengue, and typhus; Murray, Schaller, \& 
Suedfeld, 2013). The data to develop this measure were obtained by Murray and Schaller (2010) from old medical atlases and historical information related to disease prevalence. (2) Nonzoonotic and zoonotic pathogen prevalence (Fincher \& Thornhill, 2012). Fincher and Thornhill (2012) used the Global Infectious Diseases \& Epidemiology Network (GIDEON) database to calculate the prevalence of human-specific and multi-host infectious (nonzoonotic) diseases and infectious diseases which reproduce and develop entirely in nonhuman hosts, and so cannot be transmitted between humans (zoonotic diseases) per country. National values for the nonzoonotic and zoonotic parasite prevalence variables were extracted from Fincher and Thornhill's (2012) openly available dataset.

\section{Covariates: Regional Socio-Economic Variables}

To control for potential confounding socio-economic variables, in line with geographical psychology conventions (Garretsen et al., 2018; Obschonka et al., 2018; Rentfrow, 2010; Rentfrow et al., 2013), all US-based analyses controlled for the following five variables. (1) Religiosity, indexed by the proportion of people with a religious affiliation, regardless of religious denomination; (2) economic climate, reflected by the regional unemployment rate; (3) ethnic composition, measured by the proportion of white people residing in the region relative to other ethnic groups; (4) educational attainment (human capital), reflected by the proportion of individuals in the region that have at least attended college; (5) industrial composition, proportion of people working in manufacturing industries. Data were obtained from the 2010 U.S. Religion Census (http://www.usreligioncensus.org/) to quantify religiosity and from the 2016 American Community Survey (https://www.census.gov/programs-surveys/acs/news/data-releases/2016/release.html) for all other control variables. All analyses controlled for these socio-economic variables unless otherwise stated.

The cross-cultural analyses controlled for an analogous set of socio-economic variables, informed by covariates identified by past cross-cultural analyses of pathogen prevalence (Murray, Schaller, \& Suedfeld, 2013): (1) Economic climate was indexed by national unemployment rate as a percentage of the total labor force for 2016, obtained from the World Bank using the International Labour Organization estimate. (2) Religiosity was indexed by the proportion of people with a religious affiliation, regardless of religious denomination. (3) Life expectancy was measured using a method employed in previous cross-national studies (Fincher et al., 2008; Murray, Schaller, \& Suedfeld, 2013) in which average life expectancy at birth (obtained for the year 2013 from United Nations at www.hdr.undp.org) is regressed on historical pathogen prevalence index, and the residuals are saved as the life expectancy index that is independent of disease-relevant threats. (4) Educational attainment (human capital) was indexed by the United Nations Education Index scores for 2013 (obtained from www.hdr.undp.org) and residualized in the same way as life expectancy. (5) Wealth inequality was indexed by GINI coefficients obtained from the CIA World Factbook (dates of GINI scores ranged from 1997-2016). All analyses controlled for these socio-economic variables unless otherwise stated.

\section{Outcome Variables: Voting Behavior and Authoritarian Governance}

Voting Behavior (USA Analyses): To calculate regional conservative voting behavior in the U.S., data were acquired from the MIT Election Data and Science Lab (2018). Conservative votes were operationalized as the number of votes for the Republican Presidential candidate (Donald Trump) divided by the total number of votes in a region.

Authoritarian Governance (USA Analyses): To measure authoritarian governance, we used the vertical legal restrictions index, created and validated by Conway and colleagues (2017), which reflects the presence of laws in which one group of people imposes asymmetrical laws on others in a hierarchical structure. Specifically, the index reflects the presence of restrictive laws (or the absence of laws protecting freedom) in three general areas of legal restriction that have been theoretically linked to the facilitation of hierarchies in which some minority groups' freedoms are unequally restricted: abortion, extreme criminal punishment, and LGBT rights (see Conway et al., 2017 for details). These vertical legal restrictions contrast with "horizontal" restrictions, in which the laws restrict most members of a society in an equal fashion (Conway et al., 2006, 2014). Consequently, the difference between vertical and horizontal legal restrictions reflects the difference between "laws that only apply to minority groups" and "laws that apply to all persons equally," respectively. Vertical legal restrictions are therefore a proxy measure of authoritarian governance, in line with Murray and colleagues' (2013) definition of authoritarian governance as "highly concentrated power structures that repress 
dissent and emphasize submission to authority, social conformity, and hostility towards outgroups" (Murray et al., 2013, p. 1).

Authoritarian Governance (Cross-Cultural): To calculate authoritarian governance across nations, we used the established Vanhanen democracy index from the latest year available, 2012 (Vanhanen, 1997; Pemstein, Meserve, \& Melton, 2013), and $z$-scored it.

\section{Analytic Strategy}

The general analytic strategy consisted of evaluating the relationships between the measured authoritarianism measure and pathogen prevalence, while controlling for all relevant socio-economic regional covariates. This relationship is then examined in relation to a range of outcome real-world regional outcome variables linked to voting behavior and authoritarian governance. Both frequentist and Bayesian analyses were conducted to highlight the evidential strength of the reported findings. As mentioned above, covariates are included in all analyses unless explicitly stated otherwise.

\section{Mediation Analysis}

Mediation analyses were conducted using the R packages psych (Revelle, 2015) for the bias-corrected bootstrapping procedure and the R-based Monte Carlo Method for Assessing Mediation (MCMAM; Selig \& Preacher, 2008). The mediation effect size was calculated in accordance with the guidelines of Iacobucci, Saldanha, and Deng (2007) to compute the proportion of indirect effect to the total effect.

\section{Bayesian Analysis}

Bayes factors express the relative likelihood of a regression model versus a null (or a specified alternative) model given the data and certain prior expectations. To calculate Bayes factors using Bayesian regression, we relied on a default Bayesian approach promoted by Wetzels and colleagues (2011), Rouder and Morey (2012), and Liang, Paulo, Molina, Clyde, and Berger (2008), and computationally specified in the R package BayesFactor (Morey et al., 2015). We used the $\mathrm{R}$ package BayesFactor function regressionBF, which computes Bayes Factors simultaneously for a set of regression models to test the null hypothesis that slopes are equivalent to zero against the hypothesis that all slopes are nonzero. The prior scale for standardized slopes was on the default setting of $\sqrt{2} / 4$ which facilitates consistent Bayes Factors (Rouder \& Morey, 2012; Morey et al., 2015). This approach calculates the evidential strength in the data against the null hypothesis in complex regression models.

\section{Results}

\section{Are Higher Rates of Infectious Diseases Related to More Authoritarian Attitudes?}

The study examined whether infectious diseases rates are related to more authoritarian psychological dispositions across multiple geographical spatial levels: between U.S. metropolitan regions, between U.S. states, and between nations. As evident in Figure 1, infectious disease prevalence was positively related to authoritarian attitudes across U.S. metropolitan regions $(\beta=.345, p=.003)$, U.S. states $(\beta=.596, p=.033$; Figure 2$)$, and cross-culturally $(\beta=.790, p=.001)$, after controlling for all relevant socio-economic variables and sample characteristics. The full regression results for these analyses can be found in Supplementary Tables S3, S4, and S5. 


\section{Figure 1}

The Relationship Between Authoritarian Attitudes and Pathogen Prevalence Across (A) U.S. Metropolitan Regions, (B) U.S. States, and (C) Nations, Controlling for Sample Characteristics (Age and Gender) and Regional Socio-Economic Characteristics
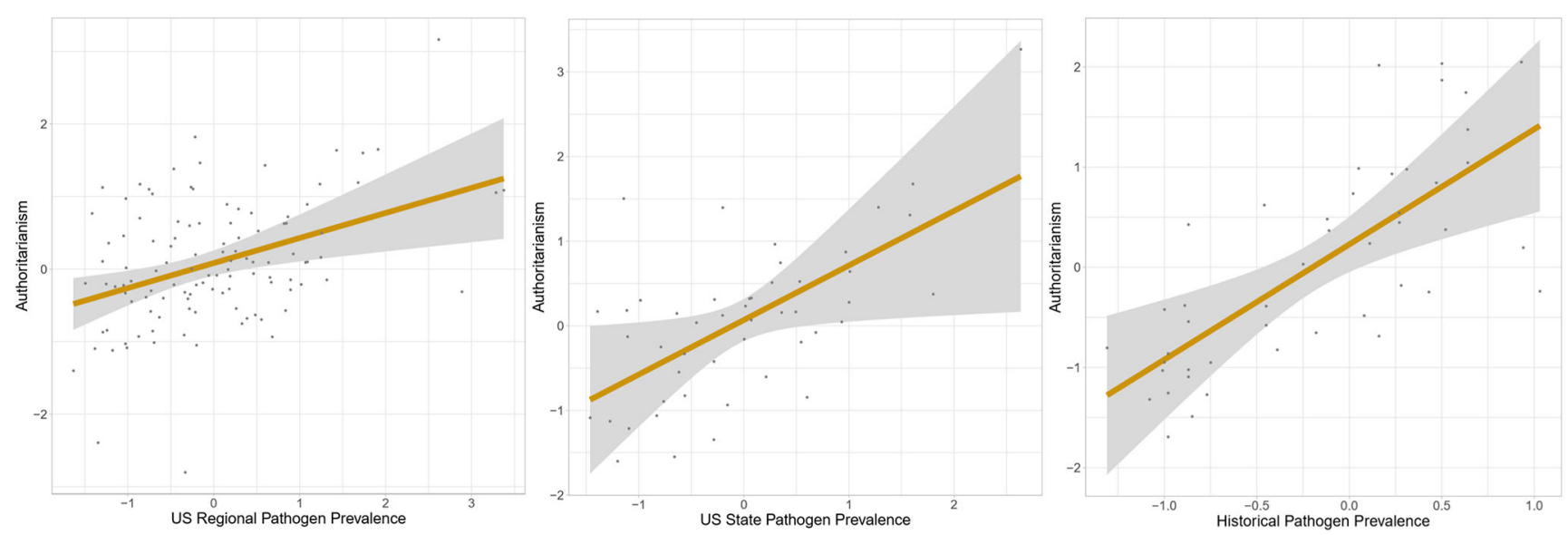

Note. USA analyses: controlling for religiosity, economic climate, educational attainment, ethnic composition, industrial composition; cross-cultural analysis: controlling for religiosity, economic climate, educational attainment, life expectancy, wealth inequality. Shaded area reflects $95 \%$ confidence intervals.

\section{Does the Relationship Between Infectious Diseases and Authoritarian Attitudes Explain Real-World Outcomes Such as Voting Behavior and Law?}

Building on previous theory and research, we examined whether infectious disease rates predict regional conservative voting behavior in the 2016 U.S. Presidential Election across metropolitan regions and states, and whether heightened authoritarian attitudes mediated these relationships. Pathogen prevalence was a significant positive predictor of the percentage of citizens in a region who voted for the Republican Presidential candidate in the 2016 U.S. Election in U.S. metropolitan regions $(\beta=.253, p=.023)$ and states $(\beta=.587, p=.004)$, controlling for sample characteristics and regional socio-economic characteristics. Consequently, mediation analyses were conducted using a bias-corrected bootstrapping procedure (MacKinnon \& Fairchild, 2009; Preacher \& Selig, 2012), with 10,000 bootstrapped iterations. To validate this further, we also employed the Monte Carlo method for testing mediation (in line with the methodological recommendations of Hayes \& Scharkow, 2013). This was achieved by constructing 95\% confidence intervals around the unstandardized indirect effects (MacKinnon et al., 2004; Preacher \& Selig, 2012), using 50,000 simulations. Confidence intervals that exclude zero are considered significant. As indicated by Figure 3, across both U.S. metropolitan regions and U.S. states, authoritarian attitudes mediated the relationship between pathogen prevalence and regional conservative political outcomes in the 2016 Election using both the bias-corrected bootstrapping procedure and the Monte Carlo procedure.

At the U.S. metropolitan regional level, as evident in Figure 3A, the total effect of pathogen prevalence on conservative voting behavior was $\beta=0.25, S E=0.09, t=2.82, d f=159, p=.006$. The direct effect after taking into account authoritarian attitudes was $\beta=0.16, S E=0.09, t=1.76, d f=158, p=.08$. The indirect effect is depicted in Figure 3A. At the U.S. state level, as evident in Figure 3B, the total effect of pathogen prevalence on conservative voting behavior was $\beta=0.61, S E=0.26, t=2.33, d f=42, p=.025$. The direct effect after taking into account authoritarian attitudes was $\beta=$ $0.23, S E=0.21, t=1.07, d f=41, p=0.29$. The indirect effect is depicted in Figure 3B.

The mediation effect sizes were large across both geographical levels, as shown in Figure 3. After accounting for authoritarianism, the direct effect between pathogen prevalence and conservative voting outcomes was no longer significant, suggesting a full mediation across both geographical levels. Consequently, heightened rates of infectious diseases were related to elevated authoritarian attitudes, which in turn were associated with more conservative political outcomes in the U.S. 
Figure 2

(Top) Authoritarianism Scores Across Nations. (Middle) Distribution of Pathogen Prevalence and Authoritarian Attitudes Across Nations. (Bottom) Distribution of Pathogen Prevalence and Authoritarian Attitudes Across U.S. States and US Metropolitan Regions

(A)

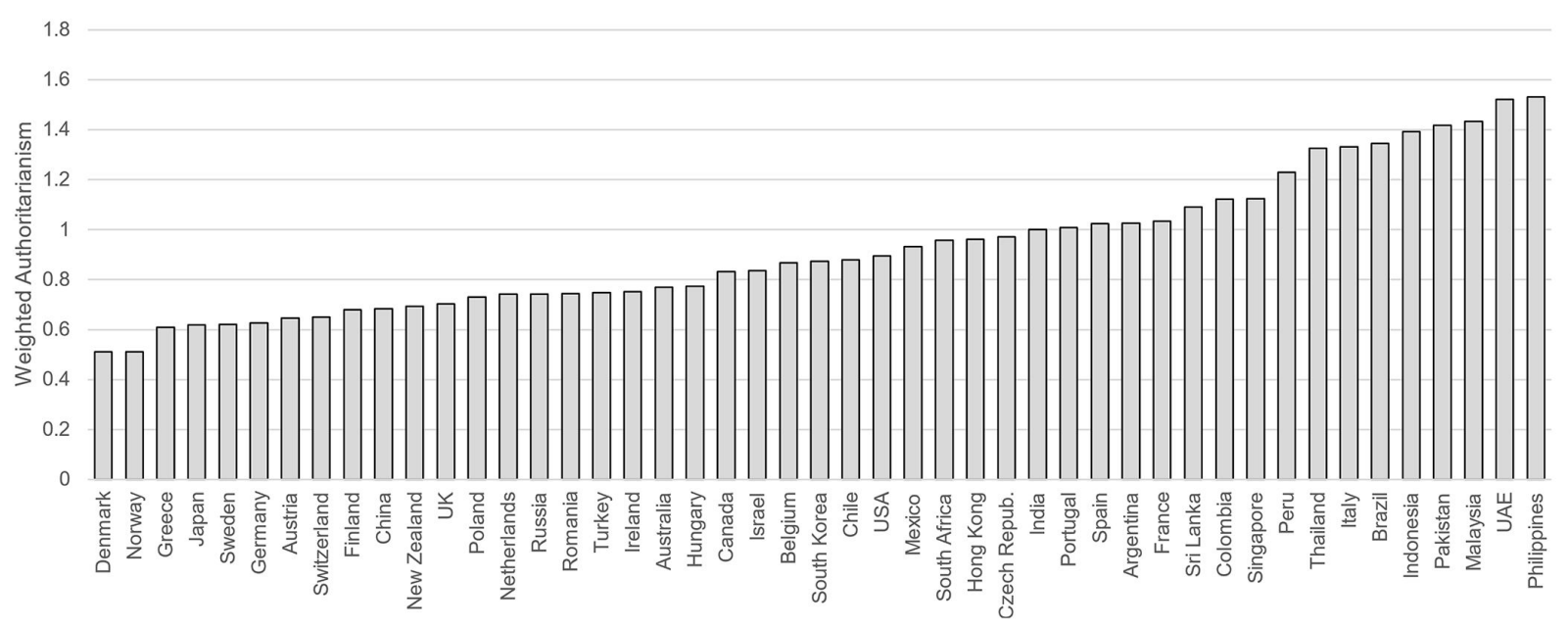

(B)

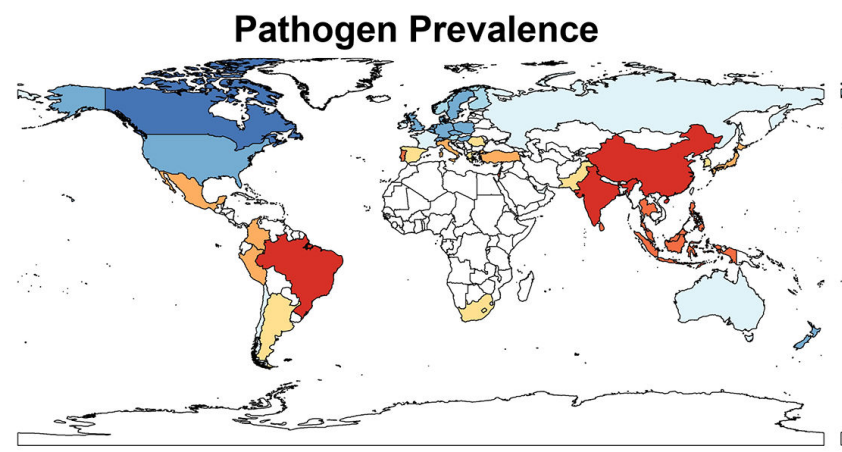

\section{Authoritarian Attitudes}

(C)

$$
\text { Pathogen Prevalence }
$$

Authoritarian Attitudes

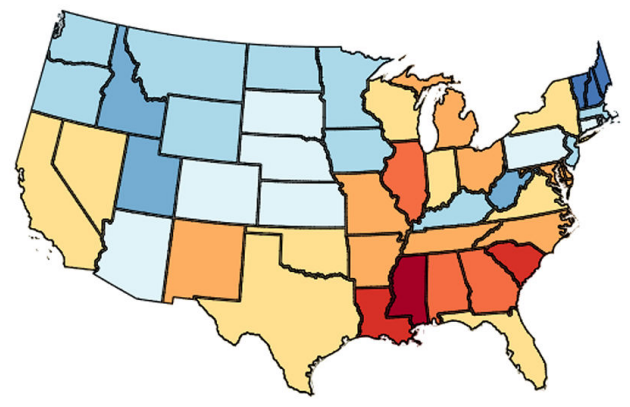

(D)

Pathogen Prevalence

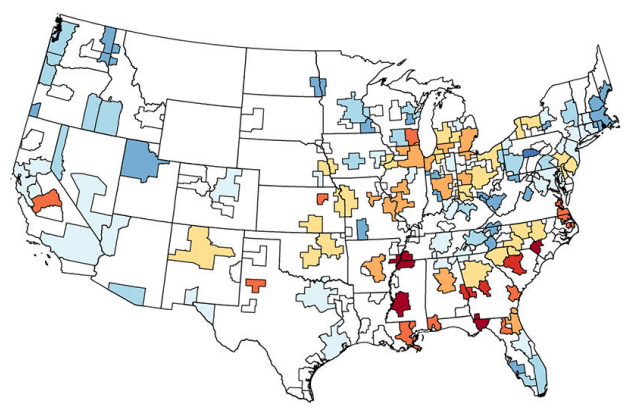

Journal of Social and Political Psychology

2021, Vol. 9(2), 456-474

https://doi.org/10.5964/jspp.7297

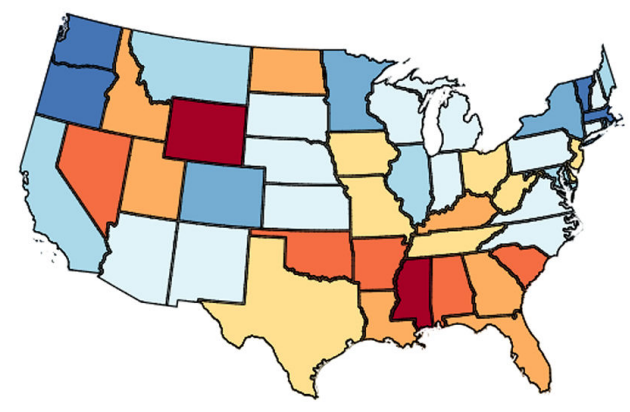

Authoritarian Attitudes

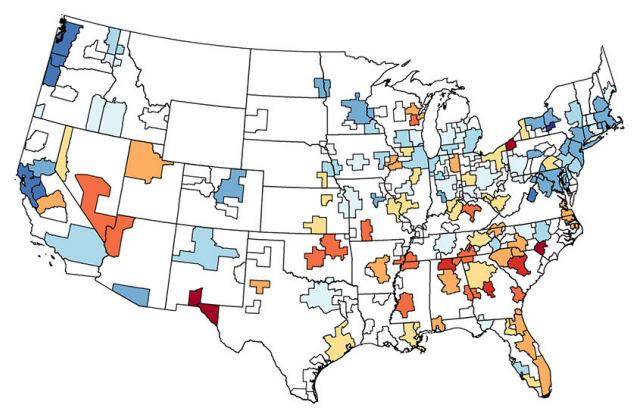

$\square$ PsychOpen ${ }^{\text {GOLD }}$ 


\section{Figure 3}

Authoritarian Attitudes Mediate the Relationship Between Regional Pathogen Prevalence and Regional Conservative Voting Behavior in the 2016 U.S. Presidential Election Across (A) U.S. Metropolitan Regions and (B) U.S. States, Controlling for Sample Characteristics (Age and Gender) and Regional SocioEconomic Characteristics (Religiosity, Economic Climate, Educational Attainment, Ethnic Composition, Industrial Composition)

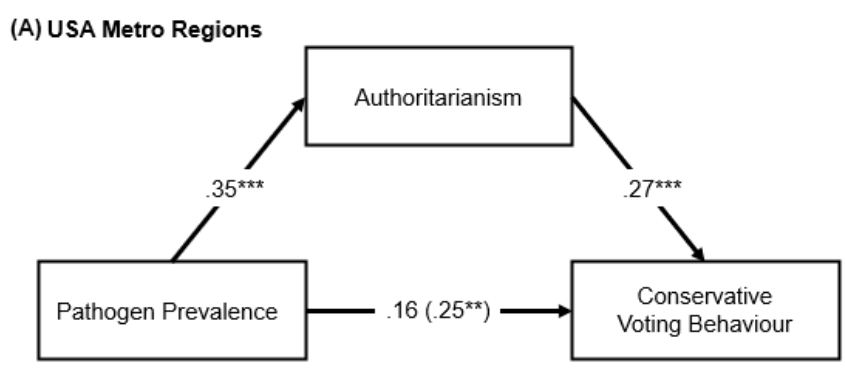

Bootstrapped indirect effect: $\beta=.10[.01, .09]$, mediation effect size: $40 \%$ Monte Carlo 95\% Cl: $[.021, .196]$
(B) USA States

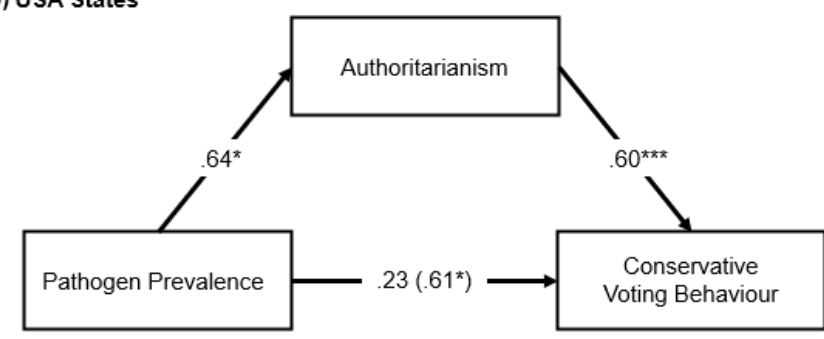

Bootstrapped indirect effect: $\beta=.41[.04, .94]$, mediation effect size: $67 \%$ Monte Carlo $95 \% \mathrm{Cl}:[.041, .791]$

Note. Values represent standardized beta coefficients. The value in parentheses indicates the total effect. Confidence intervals that exclude zero are significant.

${ }^{*} p<.05 .{ }^{* *} p<.01 .{ }^{* * *} p<.001$.

Infectious diseases and authoritarianism are thus linked to who citizens elect for political governance, and so we examined whether this pattern is also manifest with regards to how citizens are governed. Vertical legal restrictions in a state - those imposed asymmetrically and hierarchically upon specific (minority) groups - were significantly positively related to its pathogen prevalence $(r=.356, p=.013)$. In contrast, horizontal legal restrictions - which apply to all persons equally - were not significantly related to pathogen prevalence $(r=.262, p=.072)$. Vertical and horizontal legal restrictions were not correlated $(r=-.156, p=.289)$, consistent with Conway and colleagues' (2017) findings. This suggests that the vertical and horizontal legal restriction indices tap into separable constructs. Furthermore, there was a significant mediation effect of the relationship between U.S. state pathogen prevalence and authoritarian state laws via authoritarian attitudes: heightened pathogen prevalence predicted elevated levels of authoritarianism, which in turn predicted more authoritarian state governance (Figure 4A). At the U.S. state level, as evident in Figure 4A, the total effect of pathogen prevalence on vertical legal restrictions was $\beta=0.88, S E=0.33, t=2.65, d f=42, p=.011$. The direct effect after taking into account authoritarian attitudes was $\beta=0.50, S E=0.31, t=1.64, d f=41, p=0.11$, and so no longer significant. The indirect effect is depicted in Figure 4A. This suggests that vertical legal restrictions, and not merely the general presence of legal restrictions, are related to pathogen prevalence and authoritarian psychological dispositions.

To further investigate whether the relationship between pathogen prevalence and authoritarianism explained real-world outcomes, we examined authoritarian governance between nations. Following the mediation structure hypothesized by Murray and colleagues (2013), we found that undemocratic governance systems - as operationalized with the Vanhanen's index of democracy (1997, Pemstein, Meserve, \& Melton, 2013) - are related to infectious diseases and authoritarian attitudes in a similar fashion to the patterns observed on the U.S. metropolitan and state levels. The mediation persisted when accounting for the sample age and gender characteristics, but in line with the findings of Murray and colleagues (2013) and Tybur and colleagues (2016), the results did not persist after accounting for broader national socioeconomic variables such as educational attainment, wealth, and religiosity, suggesting that these variables may play a role in these relationships. Cross-cultural analyses with a larger range of countries will be more well-powered to address these nuances. This may also involve further probing the relationship between authoritarian attitudes and authoritarian governance, which could be more tightly linked in democratic societies such as the U.S. but more inconsistent in undemocratically governed societies, which might have populations with non-authoritarian attitudes but still governed in authoritarian ways. Socioeconomic indicators such as educational attainment, wealth, inequality, and others, might also obscure these relationships in undemocratic societies. 


\section{Figure 4}

(A) Authoritarian Attitudes Mediate the Relationship Between Regional Pathogen Prevalence and Authoritarian (Vertical) U.S. State Laws, Controlling for Sample Demographic Characteristics (Age and Gender) and Regional Socio-Economic Characteristics (Religiosity, Economic Climate, Educational Attainment, Ethnic Composition, Industrial composition). (B) Authoritarian Attitudes Mediate the Relationship Between Historical Pathogen Prevalence and Undemocratic Governance, Controlling for Sample Demographic Characteristics (Age and Gender)

(A) USA States

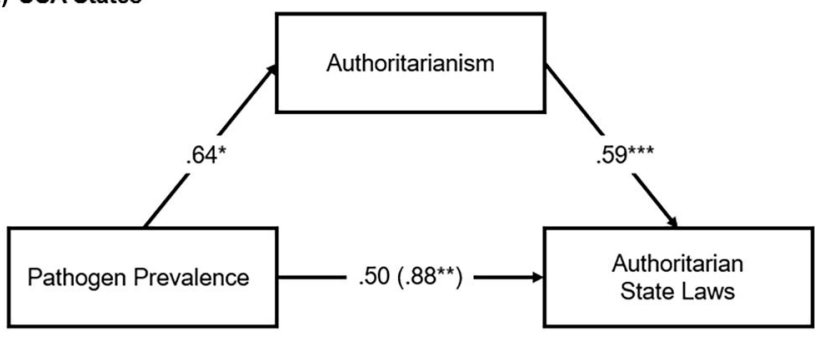

Bootstrapped indirect effect: $\beta=.38[.04, .86]$, mediation effect size: $43 \%$ Monte Carlo $95 \% \mathrm{Cl}:[.032, .842]$
(B) Cross-cultural

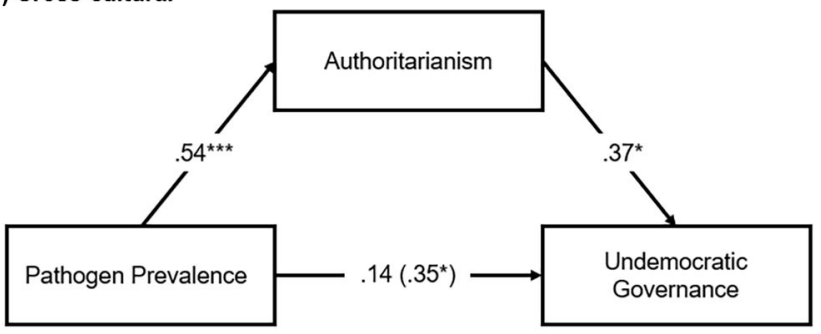

Bootstrapped indirect effect: $\beta=.21[.04, .41]$, mediation effect size: $60 \%$ Monte Carlo 95\% Cl: [.027, .488]

Note. Values represent standardized beta coefficients. The value in parentheses indicates the total effect. Confidence intervals that exclude zero are considered significant.

${ }^{*} p<.05 .{ }^{* *} p<.01 .{ }^{* * *} p<.001$.

\section{Is This Relationship Pronounced in Nonzoonotic (Human-To-Human) Infectious Diseases Rather Than Zoonotic (Asocial) Diseases?}

The parasite-stress theory of authoritarianism posits that the costs of being infected by outgroup human members would motivate more authoritarian behavior. Therefore, it predicts that infectious diseases that can be transmitted between humans would be more relevant to authoritarianism than infectious diseases that cannot be transmitted between humans (Fincher \& Thornhill, 2012; Thornhill et al., 2010; Thornhill \& Fincher, 2014). Epidemiologists have identified that there are two types of infectious diseases that humans can acquire: (1) nonzoonotic diseases, which can be acquired from other humans or animals and transmitted onto other humans (e.g., measles, cholera, leprosy), and (2) zoonotic diseases, which can only be acquired from non-human species (e.g., Lyme disease, rabies). Consequently, we tested whether nonzoonotic infectious diseases were indeed related more strongly to authoritarian attitudes than zoonotic diseases. Data on nonzoonotic and zoonotic infections is only publicly available on the cross-national level, so we analyzed it in the 47 -country dataset.

Regression analyses corroborated this hypothesis: nonzoonotic infectious diseases were more important for explaining authoritarian attitudes than zoonotic diseases. A multiple linear regression analysis predicting national authoritarian attitudes was conducted, $F(7,38)=4.634, p<.001, R^{2}=46.05 \%$, including the socio-economic covariates outlined above (all were insignificant predictors at $p>.05$ ) and the rates of nonzoonotic and zoonotic parasite prevalence. Nonzoonotic parasite prevalence was a significant positive predictor of authoritarian attitudes $(\beta=.669, t=2.656, p=.012)$, while zoonotic parasite prevalence was not a significant predictor $(\beta=-.105, t=-.544, p=.590)$. This finding was supported by a Bayesian analysis. Computing the Bayesian regressions and associated Bayes factors for all possible combinations of socio-economic predictors and the nonzoonotic and zoonotic parasite prevalence predictors allows us to balance predictive power and parsimony through the removal of redundant predictors. This analysis revealed that the best model out of all possible predictor combinations is the one that predicts authoritarianism only with the nonzoonotic parasite prevalence measure and no other socio-economic measure or the zoonotic parasite prevalence. The Bayes factor for this model was $\mathrm{BF}_{10}=17,236$, indicating that the data are 17,236 times more likely under this model than an intercept-only null model $\left(\mathrm{H}_{0}\right)$. Figure 5 depicts the Bayes factors for regression models predicting authoritarianism with a single predictor each time. Moreover, the nonzoonotic-parasite-only model (subscript $\mathrm{N}$ ) was over 13 times more likely than a model predicted by all the five socio-economic factors (subscript $\mathrm{S} ; \mathrm{BF}_{\mathrm{NS}}=13.733$ ). 


\section{Figure 5}

Regression Results Predicting National Authoritarian Attitudes From Nonzoonotic Infectious Diseases (Acquired From Humans), Zoonotic Infectious Diseases (Acquired From Non-Humans), and Socio-Economic Characteristics, Controlling for Sample Characteristics (Age and Gender)
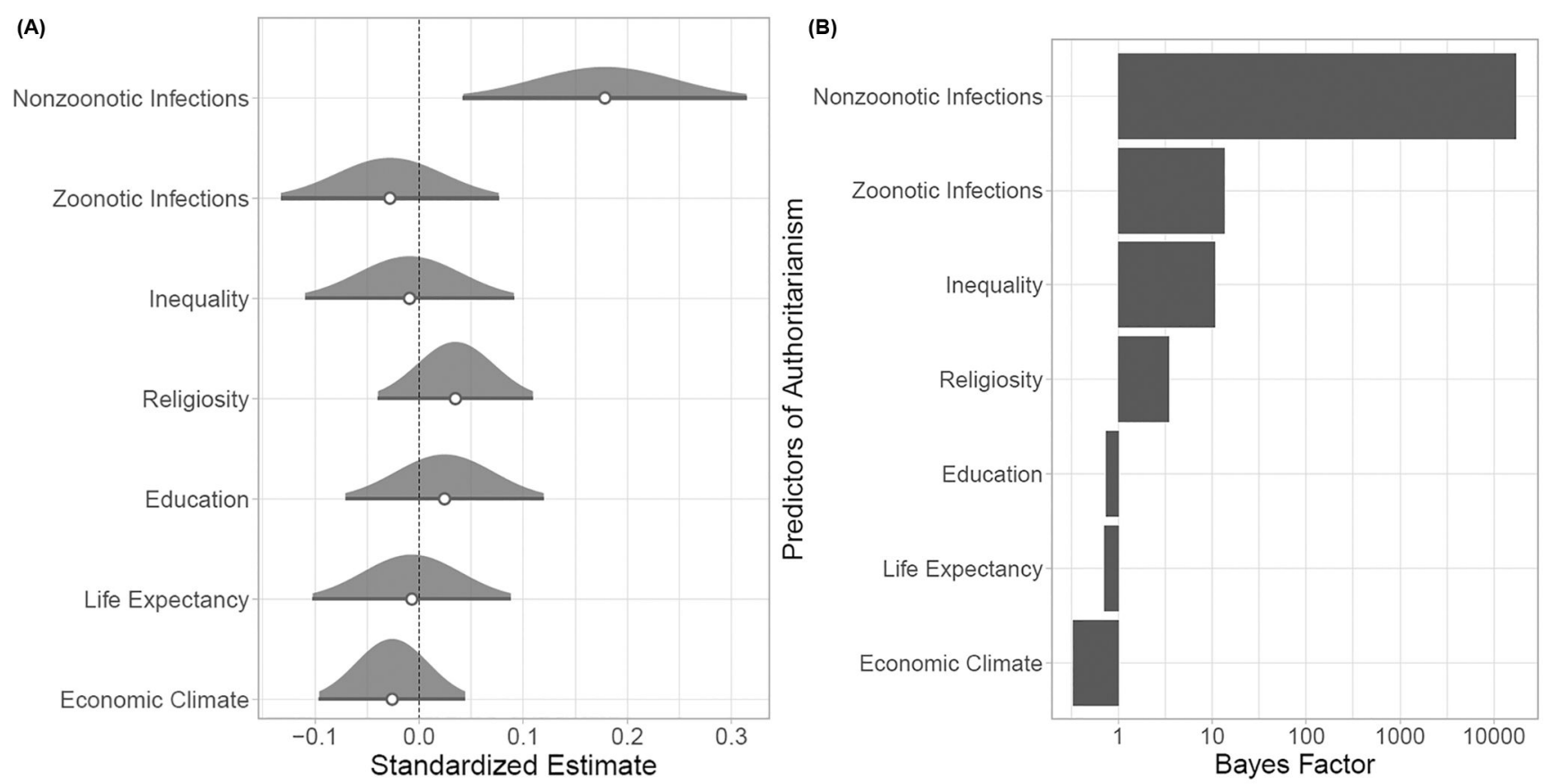

Note. (A) Standardized beta estimates with 95\% confidence intervals. (B) Bayes Factors for each predictor. In accordance with Jeffreys (1961), Bayes Factor $(\mathrm{BF})$ above 10 indicates strong evidential strength, $\mathrm{BF}>30$ indicates very strong evidence, and $\mathrm{BF}>100$ indicates decisive evidence in favor of the predictor.

\section{Discussion}

The findings reveal a robust relationship between regional infectious disease rates and psycho-political preferences for conformity and hierarchical power structures. This relationship is evident across three geographical spatial levels and predicts real-world outcomes such as conservative voting behavior and authoritarian governance. Moreover, a fine-grained analysis of infection type specifically implicates nonzoonotic infections that can be acquired from other humans - the findings do not generalize to zoonotic infections that can only be acquired from non-human species. Psychological and political behavior is thus shaped specifically by socially-relevant infections, in which the behavioral immune system (BIS) can motivate individuals to avoid dissimilar others and hence prefer authoritarian power relations. Public and personal health can therefore have fundamental repercussions for regional politics, decision-making, and governance.

The current study sheds light on the parallel links between infection rates and authoritarian attitudes across multiple geographical levels, thus addressing past limitations and criticisms of the behavioral immune system theory and approach. Interestingly, the findings reveal that the relationship between pathogen prevalence and authoritarian attitudes is at times stronger and more reliable with larger geographical units - highlighting the importance of considering the causal mechanisms that underpin small aggregate effects and how these translate, and perhaps gain salience and strength, to broader geographical units. Nonetheless, it is important to evaluate these findings in light of existing debates regarding geographical psychology and population-comparison methodology more broadly (Hruschka \& Hackman, 2014; Hruschka \& Henrich, 2013; Mace \& Jordan, 2011; Nettle, 2009; Pollet et al., 2014; Schaller \& Murray, 2011) and the various critiques and nuances of the role of the BIS in motivating individual and social political outcomes (Currie \& Mace, 2012; de Barra \& Curtis, 2012; Pollet, 2014; van Leeuwen \& Petersen, 2018). These discussions have pointed out the inferential challenges of using geographical regions as the unit of analysis - some of which are 
difficult to avoid - and so by controlling for a range of individual-level and population-level demographic variables that could potentially be confounded with higher infection rate, as well as conducting rigorous frequentist and Bayesian analyses at multiple geographic levels, we were able to show that it is possible to tighten the inferential capabilities of this methodology. Unlike most past investigations, we also examined multiple indices of infectious diseases, allowing us to reach a more fine-grained level of specificity regarding the role of nonzoonotic and zoonotic diseases (Figure 5). Although certain indices are unavailable at country-level, state-level, or metropolitan-level, we used all publicly available datasets that we could find that pertain to regional infection rates. Finally, we also moved beyond the more politically-loaded construct of right-wing authoritarianism and measured authoritarianism in a more politically-neutral way to not confound other ideological commitments to religious institutions or political parties. This is particularly important given that authoritarianism can manifest itself on the political right and the political left, depending on the individual and the social context (e.g., Conway, Houck, Gornick, \& Repke, 2018; de Regt, Mortelmans, \& Smits, 2011; Van Hiel, Duriez, \& Kossowska, 2006). Indeed, recent analyses of the authoritarianism measure used here demonstrate that it is valid, stable over time, and exogenous to political party support and issue preferences (Engelhardt, Feldman, \& Hetherington, 2021), unlike the right-wing authoritarianism scale (Satherley et al., 2021; Van Assche et al., 2019). As a result, the present investigation offers a novel and important perspective on the recurring patterns that can be seen across multiple geographical levels of analyses with regards to the relationship between individuals' authoritarianism and infectious illnesses. This highlights the specificity of socially-transmissible infections as well as the universality and generality of these effects across diverse contexts.

Nevertheless, it is important to address the limitations of the present investigation and avenues for future research. Firstly on the question of measurement, short-form questionnaires are always inherently limited in scope and depth, and the authoritarianism measure here is no exception. Engelhardt, Feldman, and Hetherington (2021) recently observed that adding more items to the childrearing measure can improve the scale's reliability and substantially diminish the proportion of respondents who receive the minimum or maximum authoritarianism score. Future research may thus benefit from complementing and testing the cross-cultural reliability of an expanded measure or alternative authoritarianism tests that avoid conflating authoritarianism with other ideological processes (e.g. Oesterreich, 2005). Indeed, there is sparse research on how authoritarianism is understood in different cultures and languages. Acknowledging these cultural effects may help account for some of the unique features of the cross-cultural analysis relative to the U.S.-based analysis, as well as the discrepancies between observations in the central tendencies of the cross-cultural data and prior research. Additionally, the participant samples in the present study were not preselected for national representativeness, and so replicating these findings in nationally representative samples is an essential next step (Vitriol, Larsen, \& Ludeke, 2019).

Methodologically and conceptually, there is also the key question of how to isolate authoritarianism from other relevant ideological processes. At the individual level, the psychological signature of authoritarianism has both overlaps and differences from other ideological tendencies such as political conservatism, nationalism, and religiosity (Zmigrod, Rentfrow, \& Robbins, 2018; Zmigrod et al., 2021). At the broader geographical level, while the current study controlled for a range of relevant socioeconomic variables, and followed existing conventions from similar geographical BIS research, the relationships between authoritarianism, religiosity, and political orientation may be complexly intertwined (Hinckley, 2021). In fact, recent evidence suggests that the relationship between authoritarianism and religiosity is stronger in societies with higher educational attainment and development (Federico, Bai, \& Aguilera, 2021). The existence of interactions between these ideological processes could help account for anomalies in the patterns observed in the present study. Future research should endeavor to search for interactions between these ideological and political variables which may explain instances that deviate from the pattern identified here and potentially clarify the applicability of the pathogen prevalence thesis in different locations. There is also a multitude of ways to measure authoritarian governance, such as from the EIU's Democracy Index or the World Bank's WGI, as well as adjacent constructs such as collectivism and individualism, and so a careful theoretically-minded investigation of the interrelationships between these measurement tools and constructs will help consolidate our understanding of the cultural manifestations of authoritarianism.

Furthermore, a more fine-grained, computationally-minded analysis of temporal and cultural dynamics (Kashima, Perfors, Ferdinand, \& Pattenden, 2021; Muthukrishna \& Schaller, 2020) might shed more light on how authoritarian 
attitudes and governance change in tandem or asynchronously, and the potential role of disease prevalence and outbreaks in modulating these processes. A recent investigation demonstrates that personality traits interact with the social context to shape citizens' social distancing behaviors during the COVID-19 pandemic (Ludeke, Vitriol, Larsen, \& Gensowski, 2021), illustrating that context, geography, and personality dispositions can have joint and amplifying effects on each other. Acknowledging these (potentially non-linear) interactions is particularly important when we consider real-life ideologically-motivated behavior such as extreme political action and violence (Zmigrod \& Goldenberg, 2021).

The results indicate that population-level epidemiological profiles of infectious diseases may structure individual-level psychological preferences as well as the allocation of social and political power. From a theoretical perspective, there are several open questions regarding the kinds of cultural and contextual effects that moderate the relationship between infectious diseases and authoritarian ideologies and institutions, including historical, coalitional, and intergroup dynamics. The complexity of these effects cannot be understated. Future research will need to adopt longitudinal designs that can rigorously test causality and evaluate how private experiences of infection and infection risk can shape psychological and political outcomes. As COVID-19 has become a global pandemic, it is imperative to consider the consequences of infectious diseases for citizens' psychology and politics. How do the explicit and implicit cultures that emerge from prevalent infectious diseases shape individuals' psychology at the micro and developmental levels? Do they shape all individuals to the same degree? The causal developmental trajectories are important because authoritarian ideologies, institutions, and broader cultural contexts can have bidirectional and cyclical relationships. Furthermore, pathogen prevalence is embedded in a web of socio-ecological systems, including climate, geographical topology, and anthropogenic environmental degradation and contact systems such as deforestation, animal trade, intensive farming, and more (Foley et al., 2005; Jones et al., 2008). Appreciating the relationships between climate change and pathogen prevalence should therefore emphasize the importance of tackling both in order to facilitate non-authoritarian political systems.

It may also be essential to identify antidotes to the effects of infections on politics. Indeed, emerging evidence suggests that chronic activation of the BIS can shape social cognition (Kavaliers \& Choleris, 2018), legal juror decision-making, and the evaluation of evidence (Brown, Rodriguez, Gretak, \& Berry, 2017; Sevi \& Eskenazi, 2018). Disease outbreaks can also increase voters' preferences for politically conservative candidates (Beall, Hofer, \& Schaller, 2016; Kim, Sherman, \& Updegraff, 2016). Notably, the cross-cultural analyses presented here show that historical pathogen prevalence still predicts contemporary ideological attitudes, and so if COVID-19 elevates the allure of authoritarian ideologies, the effects could be long-lasting. Authoritarian attitudes have bidirectional links with cognition and perception (e.g., Rollwage, Zmigrod, de-Wit, Dolan, \& Fleming, 2019; Zmigrod, 2020, 2021; Zmigrod et al., 2018, 2019, 2020, 2021; Zmigrod \& Tsakiris, 2021), sociality (e.g., Adorno et al., 1950; Pettigrew, 2016), and political institutions (e.g., Solt, 2012; Stevens, Bishin, \& Barr, 2006), and so individuals and societies need to be prepared for COVID-19 to have multidimensional psychological and political consequences.

Funding: L.Z. would like to acknowledge a Gates Cambridge Trust Scholarship and a Junior Research Fellowship by Churchill College, Cambridge. F.M.G would like to acknowledge a postdoc fellowship of the German Academic Exchange Service (DAAD).

Acknowledgments: The authors would like to thank TIME Magazine, especially Chris Wilson for his generous support in developing, implementing, and distributing the survey used to collect the data.

Competing Interests: The authors have declared that no competing interests exist.

Data Availability: For this article, three datasets are freely available (Zmigrod, Ebert, Götz, \& Rentfrow, 2021a)

\section{Supplementary Materials}

The Supplementary Materials contain the following items (for access, see Index of Supplementary Materials below): 
- Data File 1 - Nations: Psychological and regional data for the national, cross-cultural dataset. Anyone wishing to use or publish using this dataset should contact the authors (Dr Leor Zmigrod, Lz343@cam.ac.uk).

- Data File 2 - US States: Psychological and regional data for US states dataset. Anyone wishing to use or publish using this dataset should contact the authors (Dr Leor Zmigrod, Lz343@cam.ac.uk).

- Data File 3 - US Metro Regions: Psychological and regional data for US metropolitan region dataset. Anyone wishing to use or publish using this dataset should contact the authors (Dr Leor Zmigrod, Lz343@cam.ac.uk).

- Supplementary Materials: Supplementary analyses and demographic information on the samples.

\section{Index of Supplementary Materials}

Zmigrod, L., Ebert, T., Götz, F. M., \& Rentfrow, P. J. (2021a). Supplementary materials to "The psychological and socio-political consequences of infectious diseases: Authoritarianism, governance, and nonzoonotic (human-to-human) infection transmission" [Research data]. PsychOpen GOLD. https://doi.org/10.23668/psycharchives.5060

Zmigrod, L., Ebert, T., Götz, F. M., \& Rentfrow, P. J. (2021b). Supplementary materials to "The psychological and socio-political consequences of infectious diseases: Authoritarianism, governance, and nonzoonotic (human-to-human) infection transmission" [Additional analyses and information]. PsychOpen GOLD. https://doi.org/10.23668/psycharchives.5059

\section{References}

Ackerman, J. M., Hill, S. E., \& Murray, D. R. (2018). The behavioral immune system: Current concerns and future directions. Social and Personality Psychology Compass, 12(2), Article e12371. https://doi.org/10.1111/spc3.12371

Adorno, T. W., Frenkel-Brunswik, E., Levinson, D. J., \& Sanford, R. N. (1950). The authoritarian personality. New York, NY, USA: Harper.

Bastian, B., Vauclair, C. M., Loughnan, S., Bain, P., Ashokkumar, A., Becker, M., . . Fischer, R. (2019). Explaining illness with evil: Pathogen prevalence fosters moral vitalism. Proceedings of the Royal Society B, 286(1914), Article 20191576. https://doi.org/10.1098/rspb.2019.1576

Beall, A. T., Hofer, M. K., \& Schaller, M. (2016). Infections and elections: Did an Ebola outbreak influence the 2014 U.S. federal elections (and if so, how)? Psychological Science, 27(5), 595-605. https://doi.org/10.1177/0956797616628861

Brandt, M. J., \& Henry, P. J. (2012). Gender inequality and gender differences in authoritarianism. Personality and Social Psychology Bulletin, 38(10), 1301-1315. https://doi.org/10.1177/0146167212449871

Brandt, M. J., \& Reyna, C. (2014). To love or hate thy neighbor: The role of authoritarianism and traditionalism in explaining the link between fundamentalism and racial prejudice. Political Psychology, 35(2), 207-223. https://doi.org/10.1111/pops.12077

Brown, M., Rodriguez, D. N., Gretak, A. P., \& Berry, M. A. (2017). Preliminary evidence for how the behavioral immune system predicts juror decision-making. Evolutionary Psychological Science, 3(4), 325-334. https://doi.org/10.1007/s40806-017-0102-z

Conway, L. G., Bongard, K., Plaut, V., Gornick, L. J., Dodds, D. P., Giresi, T., . . Houck, S. C. (2017). Ecological origins of freedom: Pathogens, heat stress, and frontier topography predict more vertical but less horizontal governmental restriction. Personality and Social Psychology Bulletin, 43(10), 1378-1398. https://doi.org/10.1177/0146167217713192

Conway, L. G., III, Houck, S. C., \& Gornick, L. J. (2014). Regional differences in individualism and why they matter. In J. Rentfrow (Ed.), Psychological geography (pp. 31-50). Washington, DC, USA: American Psychological Association.

Conway, L. G., III, Houck, S. C., Gornick, L. J., \& Repke, M. A. (2018). Finding the Loch Ness monster: Left-wing authoritarianism in the United States. Political Psychology, 39(5), 1049-1067. https://doi.org/10.1111/pops.12470

Conway, L. G., III, Sexton, S. M., \& Tweed, R. G. (2006). Collectivism and governmentally initiated restrictions: A cross-sectional and longitudinal analysis across nations and within a nation. fournal of Cross-Cultural Psychology, 37(1), 20-41.

https://doi.org/10.1177/0022022105282293

Crawford, J. T., Brandt, M. J., Inbar, Y., \& Mallinas, S. R. (2016). Right-wing authoritarianism predicts prejudice equally toward "gay men and lesbians" and "homosexuals". Journal of Personality and Social Psychology, 111(2), Article e31. https://doi.org/10.1037/pspp0000070

Currie, T. E., \& Mace, R. (2012). Analyses do not support the parasite-stress theory of human sociality. Behavioral and Brain Sciences, 35(2), 83-85. https://doi.org/10.1017/S0140525X11000963 
de Barra, M., \& Curtis, V. (2012). Are the pathogens of out-groups really more dangerous? Behavioral and Brain Sciences, 35(2), 85-86. https://doi.org/10.1017/S0140525X11000975

de Regt, S., Mortelmans, D., \& Smits, T. (2011). Left-wing authoritarianism is not a myth, but a worrisome reality: Evidence from 13 Eastern European countries. Communist and Post-Communist Studies, 44(4), 299-308. https://doi.org/10.1016/j.postcomstud.2011.10.006

Ebert, T., Götz, F. M., Obschonka, M., Zmigrod, L., \& Rentfrow, P. J. (2019). Regional variation in courage and entrepreneurship: The contrasting role of courage for the emergence and survival of start-ups in the United States. Fournal of Personality, 87(5), 1039-1055. https://doi.org/10.1111/jopy.12454

Engelhardt, A. M., Feldman, S., \& Hetherington, M. J. (2021). Advancing the measurement of authoritarianism. Political Behavior. Advance online publication. https://doi.org/10.1007/s11109-021-09718-6

Faulkner, J., Schaller, M., Park, J. H., \& Duncan, L. A. (2004). Evolved disease-avoidance mechanisms and contemporary xenophobic attitudes. Group Processes \& Intergroup Relations, 7(4), 333-353. https://doi.org/10.1177/1368430204046142

Federico, C. M., Bai, H., \& Aguilera, R. (2021). Individual and contextual moderators of the relationship between authoritarianism and religiosity. British fournal of Social Psychology. Advance online publication. https://doi.org/10.1111/bjso.12463

Federico, C. M., Fisher, E. L., \& Deason, G. (2011). Expertise and the ideological consequences of the authoritarian predisposition. Public Opinion Quarterly, 75(4), 686-708. https://doi.org/10.1093/poq/nfr026

Feldman, S., \& Stenner, K. (1997). Perceived threat and authoritarianism. Political Psychology, 18(4), 741-770. https://doi.org/10.1111/0162-895X.00077

Fincher, C. L., \& Thornhill, R. (2012). Parasite-stress promotes in-group assortative sociality: The cases of strong family ties and heightened religiosity. Behavioral and Brain Sciences, 35(2), 61-79. https://doi.org/10.1017/S0140525X11000021

Fincher, C. L., Thornhill, R., Murray, D. R., \& Schaller, M. (2008). Pathogen prevalence predicts human cross-cultural variability in individualism/collectivism. Proceedings of the Royal Society: Series B. Biological Sciences, 275(1640), 1279-1285.

https://doi.org/10.1098/rspb.2008.0094

Foley, J. A., DeFries, R., Asner, G. P., Barford, C., Bonan, G., Carpenter, S. R., . . Snyder, P. K. (2005). Global consequences of land use. Science, 309(5734), 570-574. https://doi.org/10.1126/science.1111772

Gadermann, A. M., Guhn, M., \& Zumbo, B. D. (2012). Estimating ordinal reliability for Likert-type and ordinal item response data: A conceptual, empirical, and practical guide. Practical Assessment, Research \& Evaluation, 17(1), Article 3.

Garretsen, H., Stoker, J. I., Soudis, D., Martin, R. L., \& Rentfrow, P. J. (2018). Brexit and the relevance of regional personality traits: More psychological openness could have swung the regional vote. Cambridge fournal of Regions, Economy and Society, 11(1), 165-175. https://doi.org/10.1093/cjres/rsx031

Gebauer, J. E., Sedikides, C., Schönbrodt, F. D., Bleidorn, W., Rentfrow, P. J., Potter, J., \& Gosling, S. D. (2017). The religiosity as social value hypothesis: A multi-method replication and extension across 65 countries and three levels of spatial aggregation. Journal of Personality and Social Psychology, 113(3), e18-e39. https://doi.org/10.1037/pspp0000104

Gosling, S. D., Vazire, S., Srivastava, S., \& John, O. P. (2004). Should we trust web-based studies? A comparative analysis of six preconceptions about internet questionnaires. The American Psychologist, 59(2), 93-104. https://doi.org/10.1037/0003-066X.59.2.93

Götz, F. M., Bleidorn, W., \& Rentfrow, P. J. (2020). Age differences in Machiavellianism across the life span: Evidence from a largescale cross-sectional study. fournal of Personality, 88(5), 978-992. https://doi.org/10.1111/jopy.12545

Hackman, J., \& Hruschka, D. (2013). Fast life histories, not pathogens, account for state-level variation in homicide, child maltreatment, and family ties in the U.S. Evolution and Human Behavior, 34(2), 118-124.

https://doi.org/10.1016/j.evolhumbehav.2012.11.002

Hayes, A. F., \& Scharkow, M. (2013). The relative trustworthiness of inferential tests of the indirect effect in statistical mediation analysis: Does method really matter? Psychological Science, 24(10), 1918-1927. https://doi.org/10.1177/0956797613480187

Helzer, E. G., \& Pizarro, D. A. (2011). Dirty liberals! Reminders of physical cleanliness influence moral and political attitudes. Psychological Science, 22(4), 517-522. https://doi.org/10.1177/0956797611402514

Hetherington, M., \& Suhay, E. (2011). Authoritarianism, threat, and Americans' support for the war on terror. American fournal of Political Science, 55(3), 546-560. https://doi.org/10.1111/j.1540-5907.2011.00514.x

Hetherington, M. J., \& Weiler, J. D. (2009). Authoritarianism and polarization in American politics. New York, NY, USA: Cambridge University Press. 
Hinckley, R. A. (2021). Local existential threat, authoritarianism, and support for right-wing populism. The Social Science fournal. Advance online publication. https://doi.org/10.1080/03623319.2020.1859816

Horita, Y., \& Takezawa, M. (2018). Cultural differences in strength of conformity explained through pathogen stress: A statistical test using hierarchical Bayesian estimation. Frontiers in Psychology, 9, Article 1921. https://doi.org/10.3389/fpsyg.2018.01921

Hruschka, D. J., \& Hackman, J. (2014). When are cross-group differences a product of a human behavioral immune system? Evolutionary Behavioral Sciences, 8(4), 265-273. https://doi.org/10.1037/ebs0000013

Hruschka, D. J., \& Henrich, J. (2013). Institutions, parasites and the persistence of in-group preferences. PLoS One, 8(5), Article 63642. https://doi.org/10.1371/journal.pone.0063642

Iacobucci, D., Saldanha, N., \& Deng, X. (2007). A meditation on mediation: Evidence that structural equations models perform better than regressions. Journal of Consumer Psychology, 17(2), 139-153. https://doi.org/10.1016/S1057-7408(07)70020-7

Inbar, Y., Pizarro, D. A., \& Bloom, P. (2009). Conservatives are more easily disgusted than liberals. Cognition and Emotion, 23(4), 714-725. https://doi.org/10.1080/02699930802110007

Jeffreys, H. (1961). Theory of probability (3rd ed.). New York, NY, USA: Oxford University Press.

Jones, A., \& Fitness, J. (2008). Moral hypervigilance: The influence of disgust sensitivity in the moral domain. Emotion, 8(5), 613-627. https://doi.org/10.1037/a0013435

Jones, K. E., Patel, N. G., Levy, M. A., Storeygard, A., Balk, D., Gittleman, J. L., \& Daszak, P. (2008). Global trends in emerging infectious diseases. Nature, 451(7181), 990-993. https://doi.org/10.1038/nature06536

Kashima, Y., Perfors, A., Ferdinand, V., \& Pattenden, E. (2021). Ideology, communication and polarization. Philosophical Transactions of the Royal Society: Series B. Biological Sciences, 376(1822), Article 20200133. https://doi.org/10.1098/rstb.2020.0133

Kavaliers, M., \& Choleris, E. (2018). The role of social cognition in parasite and pathogen avoidance. Philosophical Transactions of the Royal Society: Series B. Biological Sciences, 373(1751), Article 20170206. https://doi.org/10.1098/rstb.2017.0206

Kim, H. S., Sherman, D. K., \& Updegraff, J. A. (2016). Fear of Ebola: The influence of collectivism on xenophobic threat responses. Psychological Science, 27(7), 935-944. https://doi.org/10.1177/0956797616642596

Letendre, K., Fincher, C. L., \& Thornhill, R. (2010). Does infectious disease cause global variation in the frequency of intrastate armed conflict and civil war? Biological Reviews of the Cambridge Philosophical Society, 85(3), 669-683.

https://doi.org/10.1111/j.1469-185X.2010.00133.x

Liang, F., Paulo, R., Molina, G., Clyde, M. A., \& Berger, J. O. (2008). Mixtures of g priors for Bayesian variable selection. fournal of the American Statistical Association, 103(481), 410-423. https://doi.org/10.1198/016214507000001337

Liuzza, M. T., Lindholm, T., Hawley, C. B., Gustafsson Sendén, M., Ekström, I., Olsson, M. J., \& Olofsson, J. K. (2018). Body odour disgust sensitivity predicts authoritarian attitudes. Royal Society Open Science, 5(2), Article 171091.

https://doi.org/10.1098/rsos.171091

Liuzza, M. T., Olofsson, J. K., Cancino-Montecinos, S., \& Lindholm, T. (2019). Body odor disgust sensitivity predicts stronger moral harshness toward moral violations of purity. Frontiers in Psychology, 10, Article 458. https://doi.org/10.3389/fpsyg.2019.00458

Ludeke, S. G., Vitriol, J. A., Larsen, E. G., \& Gensowski, M. (2021). Personality in a pandemic: Social norms moderate associations between personality and social distancing behaviors. Personality and Individual Differences, 177, Article 110828. https://doi.org/10.1016/j.paid.2021.110828

Mace, R., \& Jordan, F. M. (2011). Macro-evolutionary studies of cultural diversity: A review of empirical studies of cultural transmission and cultural adaptation. Philosophical Transactions of the Royal Society of London: Series B. Biological Sciences, 366(1563), 402-411. https://doi.org/10.1098/rstb.2010.0238

MacKinnon, D. P., \& Fairchild, A. J. (2009). Current directions in mediation analysis. Current Directions in Psychological Science, 18(1), 16-20. https://doi.org/10.1111/j.1467-8721.2009.01598.x

MacKinnon, D. P., Lockwood, C. M., \& Williams, J. (2004). Confidence limits for the indirect effect: Distribution of the product and resampling methods. Multivariate Behavioral Research, 39(1), 99-128. https://doi.org/10.1207/s15327906mbr3901_4

Mavor, K. I., Louis, W. R., \& Laythe, B. (2011). Religion, prejudice, and authoritarianism: Is RWA a boon or bane to the psychology of religion? fournal for the Scientific Study of Religion, 50(1), 22-43. https://doi.org/10.1111/j.1468-5906.2010.01550.x

Mavor, K. I., Macleod, C. J., Boal, M. J., \& Louis, W. R. (2009). Right-wing authoritarianism, fundamentalism and prejudice revisited: Removing suppression and statistical artefact. Personality and Individual Differences, 46(5-6), 592-597.

https://doi.org/10.1016/j.paid.2008.12.016 
MIT Election Data and Science Lab. (2018). County Presidential Election Returns 2000-2016 (V6, UNF:6:ZZe1xuZ5H214NUiSRcRf8Q== [fileUNF]) [Data set]. Harvard Dataverse. https://doi.org/10.7910/DVN/VOQCHQ

Morey, R. D., Rouder, J. N., Jamil, T., \& Morey, M. R. D. (2015). Package 'bayesfactor' [Computer software]. Retrieved from https://cran.r-project.org/web/packages/BayesFactor/BayesFactor.pdf

Murray, D. R., Kerry, N., \& Gervais, W. M. (2019). On disease and deontology: Multiple tests of the influence of disease threat on moral vigilance. Social Psychological \& Personality Science, 10(1), 44-52. https://doi.org/10.1177/1948550617733518

Murray, D. R., \& Schaller, M. (2010). Historical prevalence of infectious diseases within 230 geopolitical regions: A tool for investigating origins of culture. fournal of Cross-Cultural Psychology, 41(1), 99-108. https://doi.org/10.1177/0022022109349510

Murray, D. R., \& Schaller, M. (2012). Threat(s) and conformity deconstructed: Perceived threat of infectious disease and its implications for conformist attitudes and behavior. European fournal of Social Psychology, 42(2), 180-188. https://doi.org/10.1002/ejsp.863

Murray, D. R., \& Schaller, M. (2016). The behavioral immune system: Implications for social cognition, social interaction, and social influence. In Advances in experimental social psychology (Vol. 53, pp. 75-129). Cambridge, MA, USA: Academic Press.

Murray, D. R., Schaller, M., \& Suedfeld, P. (2013). Pathogens and politics: Further evidence that parasite prevalence predicts authoritarianism. PLoS One, 8(5), Article e62275. https://doi.org/10.1371/journal.pone.0062275

Murray, D. R., Trudeau, R., \& Schaller, M. (2011). On the origins of cultural differences in conformity: Four tests of the pathogen prevalence hypothesis. Personality and Social Psychology Bulletin, 37(3), 318-329. https://doi.org/10.1177/0146167210394451

Muthukrishna, M., \& Schaller, M. (2020). Are collectivistic cultures more prone to rapid transformation? Computational models of cross-cultural differences, social network structure, dynamic social influence, and cultural change. Personality and Social Psychology Review, 24(2), 103-120. https://doi.org/10.1177/1088868319855783

Navarrete, C. D., \& Fessler, D. M. (2005). Normative bias and adaptive challenges: A relational approach to coalitional psychology and a critique of terror management theory. Evolutionary Psychology, 3(1), Article 147470490500300121. https://doi.org/10.1177/147470490500300121

Navarrete, C. D., \& Fessler, D. M. (2006). Disease avoidance and ethnocentrism: The effects of disease vulnerability and disgust sensitivity on intergroup attitudes. Evolution and Human Behavior, 27(4), 270-282.

https://doi.org/10.1016/j.evolhumbehav.2005.12.001

Nettle, D. (2009). Ecological influences on human behavioural diversity: A review of recent findings. Trends in Ecology \& Evolution, 24(11), 618-624. https://doi.org/10.1016/j.tree.2009.05.013

Obschonka, M., Stuetzer, M., Rentfrow, P. J., Lee, N., Potter, J., \& Gosling, S. D. (2018). Fear, populism, and the geopolitical landscape: The "sleeper effect" of neurotic personality traits on regional voting behavior in the 2016 Brexit and Trump elections. Social Psychological \& Personality Science, 9(3), 285-298. https://doi.org/10.1177/1948550618755874

Oesterreich, D. (2005). Flight into security: A new approach and measure of the authoritarian personality. Political Psychology, 26(2), 275-298. https://doi.org/10.1111/j.1467-9221.2005.00418.x

Pemstein, D., Meserve, S. A., \& Melton, J. (2013). Replication data for: Democratic compromise: A latent variable analysis of ten measures of regime type (V2) [Dataset]. Harvard Dataverse. https://doi.org/10.7910/DVN/WWYOHU

Pettigrew, T. F. (2016). In pursuit of three theories: Authoritarianism, relative deprivation, and intergroup contact. Annual Review of Psychology, 67, 1-21. https://doi.org/10.1146/annurev-psych-122414-033327

Pollet, T. V. (2014). A re-analysis of the relationship between "parasite stress" and authoritarianism. Frontiers in Psychology, 5, Article 638. https://doi.org/10.3389/fpsyg.2014.00638

Pollet, T. V., Tybur, J. M., Frankenhuis, W. E., \& Rickard, I. J. (2014). What can cross-cultural correlations teach us about human nature? Human Nature, 25(3), 410-429. https://doi.org/10.1007/s12110-014-9206-3

Preacher, K. J., \& Selig, J. P. (2012). Advantages of Monte Carlo confidence intervals for indirect effects. Communication Methods and Measures, 6(2), 77-98. https://doi.org/10.1080/19312458.2012.679848

Rentfrow, P. J. (2010). Statewide differences in personality: Toward a psychological geography of the United States. The American Psychologist, 65(6), 548-558. https://doi.org/10.1037/a0018194

Rentfrow, P. J., Gosling, S. D., Jokela, M., Stillwell, D. J., Kosinski, M., \& Potter, J. (2013). Divided we stand: Three psychological regions of the United States and their political, economic, social, and health correlates. fournal of Personality and Social Psychology, 105(6), 996-1012. https://doi.org/10.1037/a0034434 
Revelle, W. (2015). Package 'psych' [Computer software]. The Comprehensive R Archive Network. Retrieved from https://cran.r-project.org/

Rollwage, M., Zmigrod, L., de-Wit, L., Dolan, R. J., \& Fleming, S. M. (2019). What underlies political polarization? A manifesto for computational political psychology. Trends in Cognitive Sciences, 23(10), 820-822. https://doi.org/10.1016/j.tics.2019.07.006

Rouder, J. N., \& Morey, R. D. (2012). Default Bayes factors for model selection in regression. Multivariate Behavioral Research, 47(6), 877-903. https://doi.org/10.1080/00273171.2012.734737

Satherley, N., Sibley, C. G., \& Osborne, D. (2021). Ideology before party: Social dominance orientation and right-wing authoritarianism temporally precede political party support. British fournal of Social Psychology, 60(2), 509-523. https://doi.org/10.1111/bjso.12414

Schaller, M., \& Murray, D. R. (2011). Infectious disease and the creation of culture. In M. J. Gelfand, C.-y. Chiu, \& Y.-y. Hong (Eds.), Advances in culture and psychology (pp. 99-151). New York, NY, USA: Oxford University Press.

Schnall, S. (2017). Disgust as embodied loss aversion. European Review of Social Psychology, 28(1), 50-94. https://doi.org/10.1080/10463283.2016.1259844

Selig, J. P., \& Preacher, K. J. (2008, June). Monte Carlo method for assessing mediation: An interactive tool for creating confidence intervals for indirect effects [Computer software]. Available from http://quantpsy.org/

Sevi, B., \& Eskenazi, T. (2018). The impact of perceived threat of infectious disease on the framing effect. Evolutionary Psychological Science, 4(3), 340-346. https://doi.org/10.1007/s40806-018-0145-9

Solt, F. (2012). The social origins of authoritarianism. Political Research Quarterly, 65(4), 703-713. https://doi.org/10.1177/1065912911424287

Stenner, K. (2005). The authoritarian dynamic. New York, NY, USA: Cambridge University Press.

Stevens, D., Bishin, B. G., \& Barr, R. R. (2006). Authoritarian attitudes, democracy, and policy preferences among Latin American elites. American fournal of Political Science, 50(3), 606-620. https://doi.org/10.1111/j.1540-5907.2006.00204.x

Stewart, P. A., Adams, T. G., Jr., \& Senior, C. (2020). The effect of trait and state disgust on fear of God and sin. Frontiers in Psychology, 11, Article 51. https://doi.org/10.3389/fpsyg.2020.00051

Stuetzer, M., Audretsch, D. B., Obschonka, M., Gosling, S. D., Rentfrow, P. J., \& Potter, J. (2018). Entrepreneurship culture, knowledge spillovers and the growth of regions. Regional Studies, 52(5), 608-618. https://doi.org/10.1080/00343404.2017.1294251

Terrizzi, J. A., Shook, N. J., \& McDaniel, M. A. (2013). The behavioral immune system and social conservatism: A meta-analysis. Evolution and Human Behavior, 34(2), 99-108. https://doi.org/10.1016/j.evolhumbehav.2012.10.003

Thornhill, R., \& Fincher, C. L. (2014). The parasite-stress theory of values and sociality: Infectious disease, history and human values worldwide. Cham, Switzerland: Springer.

Thornhill, R., Fincher, C. L., \& Aran, D. (2009). Parasites, democratization, and the liberalization of values across contemporary countries. Biological Reviews of the Cambridge Philosophical Society, 84(1), 113-131. https://doi.org/10.1111/j.1469-185X.2008.00062.x

Thornhill, R., Fincher, C. L., Murray, D. R., \& Schaller, M. (2010). Zoonotic and nonzoonotic diseases in relation to human personality and societal values: Support for the parasite-stress model. Evolutionary Psychology, 8(2), Article 147470491000800201.

https://doi.org/10.1177/147470491000800201

Tybur, J. M., Inbar, Y., Aarøe, L., Barclay, P., Barlow, F. K., De Barra, M., . . Consedine, N. S. (2016). Parasite stress and pathogen avoidance relate to distinct dimensions of political ideology across 30 nations. Proceedings of the National Academy of Sciences of the United States of America, 113(44), 12408-12413. https://doi.org/10.1073/pnas.1607398113

Van Assche, J., Dhont, K., \& Pettigrew, T. F. (2019). The social-psychological bases of far-right support in Europe and the United States. Journal of Community \& Applied Social Psychology, 29(5), 385-401. https://doi.org/10.1002/casp.2407

Vanhanen, T. (1997). Prospects of democracy: A study of 172 countries. New York, NY, USA: Psychology Press.

Van Hiel, A., Duriez, B., \& Kossowska, M. (2006). The presence of left-wing authoritarianism in Western Europe and its relationship with conservative ideology. Political Psychology, 27(5), 769-793. https://doi.org/10.1111/j.1467-9221.2006.00532.x

van Leeuwen, F., Park, J. H., Koenig, B. L., \& Graham, J. (2012). Regional variation in pathogen prevalence predicts endorsement of group-focused moral concerns. Evolution and Human Behavior, 33(5), 429-437. https://doi.org/10.1016/j.evolhumbehav.2011.12.005

van Leeuwen, F., \& Petersen, M. B. (2018). The behavioral immune system is designed to avoid infected individuals, not outgroups. Evolution and Human Behavior, 39(2), 226-234. https://doi.org/10.1016/j.evolhumbehav.2017.12.003

Vitriol, J. A., Larsen, E. G., \& Ludeke, S. G. (2019). The generalizability of personality effects in politics. European fournal of Personality, 33(6), 631-641. https://doi.org/10.1002/per.2222 
Wetzels, R., Matzke, D., Lee, M. D., Rouder, J. N., Iverson, G. J., \& Wagenmakers, E. J. (2011). Statistical evidence in experimental psychology: An empirical comparison using $855 \mathrm{t}$ tests. Perspectives on Psychological Science, 6(3), 291-298. https://doi.org/10.1177/1745691611406923

Wu, B. P., \& Chang, L. (2012). The social impact of pathogen threat: How disease salience influences conformity. Personality and Individual Differences, 53(1), 50-54. https://doi.org/10.1016/j.paid.2012.02.023

Zakrzewska, M., Olofsson, J. K., Lindholm, T., Blomkvist, A., \& Liuzza, M. T. (2019). Body odor disgust sensitivity is associated with prejudice towards a fictive group of immigrants. Physiology \& Behavior, 201, 221-227. https://doi.org/10.1016/j.physbeh.2019.01.006

Zmigrod, L. (2020). The role of cognitive rigidity in political ideologies: Theory, evidence, and future directions. Current Opinion in Behavioral Sciences, 34, 34-39. https://doi.org/10.1016/j.cobeha.2019.10.016

Zmigrod, L. (2021). A neurocognitive model of ideological thinking. Politics and the Life Sciences. Advance online publication. https://doi.org/10.1017/pls.2021.10

Zmigrod, L., Eisenberg, I. W., Bissett, P. G., Robbins, T. W., \& Poldrack, R. A. (2021). The cognitive and perceptual correlates of ideological attitudes: A data-driven approach. Philosophical Transactions of the Royal Society: Series B. Biological Sciences, 376(1822), Article 20200424. https://doi.org/10.1098/rstb.2020.0424

Zmigrod, L., \& Goldenberg, A. (2021). Cognition and emotion in extreme political action: Individual differences and dynamic interactions. Current Directions in Psychological Science, 30(3), 218-227. https://doi.org/10.1177/0963721421993820

Zmigrod, L., Rentfrow, P. J., \& Robbins, T. W. (2018). Cognitive underpinnings of nationalistic ideology in the context of Brexit. Proceedings of the National Academy of Sciences of the United States of America, 115(19), E4532-E4540. https://doi.org/10.1073/pnas.1708960115

Zmigrod, L., Rentfrow, P. J., \& Robbins, T. W. (2019). Cognitive inflexibility predicts extremist attitudes. Frontiers in Psychology, 10, Article 989. https://doi.org/10.3389/fpsyg.2019.00989

Zmigrod, L., Rentfrow, P. J., \& Robbins, T. W. (2020). The partisan mind: Is extreme political partisanship related to cognitive inflexibility? fournal of Experimental Psychology: General, 149(3), 407-418. https://doi.org/10.1037/xge0000661

Zmigrod, L., \& Tsakiris, M. (2021). Computational and neurocognitive approaches to the political brain: Key insights and future avenues for political neuroscience. Philosophical Transactions of the Royal Society of London: Series B. Biological Sciences, 376(1822), Article 20200130. 